\title{
19 \\ Encouraging Learners to Prepare Oral Presentations Using Computers
}

\author{
Erol Inelmen
}

Faculty of Education, Bogazici University, Turkey

inelmen@boun edu.tr

Keywords: collaborative learning, teacher education, secondary education

\begin{abstract}
One of the most important contributions of modern technology has been in improving communication between 'learning parties' during the educational process. Although the using computers to prepare presentations can be very rewarding, unfortunately many professionals are not well trained to make effective presentations. In this paper we share the experience gained with students from the faculty of education delivering instructional material on special topics of general interest. Presentation skills where enhanced when a creative and collaborative environment was created. It is hoped that the WCEE 2001 conference will provide 'leaming parties' with a network where to share their gained experience.
\end{abstract}

\section{INTRODUCTION}

The Turkish Ministry of Education has for more than a decade now made great efforts to implement a 'computer based learning' scheme in the secondary schools (MEB 1997). Support from international banks and agencies have made it possible to provide secondary schools with the necessary hardware. Concurrently educational software has been developed with the contribution of the Turkish National Research Council (TUBITAK 1998). Recently the Turkish National Higher Education Council has mandated that graduate and undergraduate programs in computer education 
and educational technology be started in 14 of the 72 local universities (YOK 1999).

We can observe encouraging improvements in computer literacy performance of secondary school students now entering the universites. But we feel that there is still room for improvement in the method and content of teaching. Experience gained during the last five years in the university where the author is affiliated, highlights the need to develop professional skills way beyond the level of expertise the students are provided with. Given a specific topic, graduates should be able to work on a 'road-map' for a presentation and develop the material in an easy-to-follow format and include in the document information for further work.

This paper urges national and international educational parties to encourage the use of computers in the preparation of effective oral presentations in three main sections: a) needs for education reform, b) oral presentations and c) future work.

\section{NEED FOR EDUCATION REFORM}

Kant (1999) was one of the many thinkers that throughout the centuries were involved in the enhancement of education. In his view, the art of education brings human "nature one step nearer to perfection". He provided many recommendations for the physical, cultural, personal, moral and practical education of youth: "man can only become a man by education". We now wish to quote from the UNESCO report named, Learning: The Treasure Within, prepared by a Commission headed by Jacques Delors published in 1996:

"There is, therefore, every reason to place renewed emphasis on the moral and cultural dimensions of education, enabling each person to grasp the individuality of other people and to understand the world's erratic progression towards a certain unity; but this process must begin with self-understanding through an inner voyage whose milestones are knowledge, meditation and the practice of self-criticism."

The report describes the four pillars of education - learning to know, learning to be, learning to do and learning to share - as a focus to improve the present conditions if we are looking for a better future in this our planet (UNESCO 1996). Unfortunately educational methods applying the traditional disciplinary boundaries are not adequate anymore to solve the expectations of today. Although universities - in order to cope with these changes - have created research centres that work with more interdisciplinary approaches, the discipline-oriented departmental system of 
education has survived. Pressure from existing budget regulations, established professional chambers, perceptions and expectations from the community prevents overturning 'the pseudo barriers' that exist between departments.

As the economic conditions in the world change, graduates find themselves coping with altogether foreign problems. Since future developments are unpredictable, continuous learning - a lifelong process - is the solution to the adaptability needed when new situations arise. While promoting teaching the art of applying various tools to problems that require the use of resources for the convenience of men, an education system should develop the ability of self learning in the suggested 'common fields of activities'. The fact that textbooks are written along disciplinary lines puts barriers between disciplines. When students are to be allowed to make their decisions regarding their education, fitting education to their abilities, counselling systems must be implemented (Yerlici 1987a).

Trying to make changes in education to cope with current developments by simply revising 'here and there' old methods of teaching is dangerous. Professionals, who are required to have the ability of communicating with others, are expected to find economical, practical, durable, innovative, aesthetic, safe clean solutions to human needs (Yerlici 1987b). Students must have experience in applying the basic principles to real problems, whatever these problems may be in the next decades. This requirement is at odds with the traditional education system that is based on formal lecturing. Radical changes are thus necessary: the assignment of projects can provide the proper environment for the students to develop the abilities to solve real problems (Yerlici 1989).

As a measure for reform, it is proposed that higher education should a) improve the ability to question and seek for answers, b) sharpen the vision of details, and c) refine the mind for greater sophistication at interpreting data and encourage independent thinking by allowing students observe masters doing their research work (Yerlici 1991, Yerlici 1992). While providing the basic knowledge, good teachers should stimulate the minds of their students towards critical thinking and creativity. Research activities, vital for raising funds and building public image that will attract better students, should not hinder the efficiency of teaching activities (Yerlici 1993).

\section{ORAL PRESENTATIONS}

Conventional 'Technological Mediated Learning' (TML) educational material emulates classical teaching techniques that have been implemented over the centuries. No matter how fancy TML is made by using sophisticated 
multimedia techniques, the students are expected to follow the guidelines given as passive agents. This situation leads inevitably to the same boring environment that lectures and textbooks are always blamed for. The following case study shows that by encouraging students to prepare the own educational material, a creative environment where the learner takes a fully active role and make learning fun is created. A holistic framework is suggested as a general educational program, which includes Social, Economic, Political, Legal, Spiritual, Ecological, Technological, Medical, Cultural and Educational fields of knowledge.

The author implemented a novel program of education during the spring semester of the 1999-2000 academic year at his university. A group of 38 university students from the Faculty of Education participated in the 'Introduction to Computers' course, designed to develop the basic communication skills required today in daily life using emerging technologies. The method adopted there was the result of many years of experience gained by the author while using computers as tools for learning.

\begin{tabular}{|l|}
\hline Ideology \\
\hline Secularism (mutlu) \\
\hline Republicanism (bulut) \\
\hline Nationalism (oksuz) \\
\hline Estatisme (kapucu) \\
\hline Revolutionism (gonullu) \\
\hline Reforms \\
\hline Hat (gunoz) \\
\hline Constitution (yazlik) \\
\hline Democracy (arin) \\
\hline Language (akbay) \\
\hline Early (yilmaz) \\
\hline Amasya (bayhan) \\
\hline Erzurum (degirmenci) \\
\hline sivas (bayraktar) \\
\hline Caliphate (ozturk) \\
\hline March 31 (gocmen) \\
\hline 1950 (yucel) \\
\hline
\end{tabular}

\begin{tabular}{|l|}
\hline Relations \\
\hline Germany (evci) \\
\hline Japan (sendogan) \\
\hline URSS (recepoglu) \\
\hline Pacts \\
\hline Capitulations (kirbi) \\
\hline Lausanne (yasar) \\
\hline Nato (hocaoglu) \\
\hline Conflicts \\
\hline Canakkale (ozcelik) \\
\hline Sakarya (baltali) \\
\hline WW-II (baltali) \\
\hline People \\
\hline Enver (akpinar) \\
\hline Inonu (ince) \\
\hline Groups \\
\hline New-Osman (uyrum) \\
\hline Jon-Turk (kunduz) \\
\hline
\end{tabular}

Figure 1. Topics covered by 'Introduction to Computers Course'

Turkish History during the period between 1860 and 1960 was selected as the class general topic, each student sharing a unique subject matter. The objective was to encourage students to develop their own learning material following a weekly schedule which included the description of the key- 
words, the design of a roadmap of the presentation and the preparation of the presentation material using animation techniques. In Figure 1 we can see the classification of topics covered in the course.

The students prepared drafts on paper for the presentation slides and then transferred the approved material on the computer followed whenever possible by oral presentations. Make-ups were not allowed and grades points were deducted for the late of the presentations.

The standard grading system generally accepted was adopted as the basis for final assessment. Students not familiar with this 'project centred learning' approach, had difficulties adapting during the first weeks. Nevertheless performance improved as pride on the work accomplished became - without the pressure of grading - the main concern.

Although collaboration between students was not encouraged, in some cases it was inevitable. For the sake of checking the authenticity of the work, short examinations were given whenever possible. By the end of the semester students were requested to make one peer-evaluation and prepared the final own examination questions. There is no doubt that, although puzzled with the educational method adopted by the instructor, students enjoyed in most cases with this new learning approach. All the documents can be seen in web page folder (BU 1999).

Results obtained at the end of the semester were very encouraging. Students in many cases confessed that they were completely unfamiliar with some the themes of their own history. Presenting their contributions in class demanded effort to develop both written and oral presentation skills. This experience showed the need for a publication that would give learners a step by step method in public presentation. Such a document can now be found in the files car.ppt and mpp00.ppt in the new web page hamlin.cc.boun.edu.tr/ inelmen.

Curiously enough the author was involved another project that started at the same time for students in the areas affected by the recent earthquake in Turkey. A mobile bus furnished with 18 personal computers made visits to schools in the area. Here primary and secondary students got hands-on experience in the use of modern technology.

\section{FUTURE WORK}

Modern technology can provide efficient tools for communication that would eventually enhance the dialogue between cultures and lead hopefully towards world peace. There are some good examples available.

One good example is the implementation in Scotland as the home to Britain's first 'cyber school' which is in operation since August 2000. Up to 
60 pupils were connected at the wired academy (BBC 1999). The WorLD project, implementing modern educational technologies in emerging areas, is being now sponsored by the World Bank (WB 1999).

The British Broadcasting Corporation (BBC), well known for offering reliable world news, has included the graphically three dimensional interactive presentation of Bury St. Edmunds Cathedral in the United Kingdom (BBC 2000). Very attractive web sites give comprehensive information about cultural life in Australia (1999), including the charming Salamanca Market in Hobart located in the island of Tasmania (1999).

\section{CONCLUSION}

Recent economic and social developments in the world require that education be re-engineered to deal with the life-long requirements of all the citizens in the community. Developing the necessary skills for self-learning is the only way to cope with these changes. Learners should be able to present their ideas orally to different groups by the effective use of modern technologies.

As a concluding note we wish to recall the story of a traveller that amazed with the beauties he saw in the construction site of a new building he was visiting for the first time, asked an artisan what he was doing. The artisan answered reluctantly that he was putting bricks one on top of the other. The traveller moved on and asked a second artisan the same question. This time the artisan answered by explaining that he was building the wall of the government's new headquarters. Satisfied with the second answer, the traveller repeated exactly the same question to a seemingly more experienced artisan. The third artisan answered enthusiastically: "I am proud of working on the wall of a building that will be in the future the pride of our citizens".

This paper gives evidence that students have pride in and enjoy learning if an environment that will encourage creative and collaborative work is provided. Vertical and horizontal integration in education will create the holistic educational approach that is needed in the information age.

\section{ACKNOWLEDGMENTS}

The inspirations of Prof. Avadis Hacinliyan and the financial support of the Research Fund of Bogazici University are acknowledged, as well as the dedication of the 38 students that prepared remarkable presentations. 


\section{REFERENCES}

Australia (1999) [www.csu.edu.au/australia/culture.html].

BBC (1999) [news.bbc.co.uk/hi/english/uk/scotland/newsid_683000/683098.stm].

BBC (2000) [www.bbc.co.uk/history/programmes/cathedral/abbey2/abbey_inside.wrl].

BU (1999) [www.yeditepe.edu.tr/ eor/ders].

Kant, I. (1999) Education. The University of Michigan, Michigan, p. 6.

MEB (1997) Turkish Ministry of Education startegies web site

[www.meb.gov.tr/index $2 . \mathrm{htm}$ ].

Tasmania (2000) [203.16.7.7/guidcity/salamanc.htm].

TUBITAK (1998) Turkish National Research Council web site [www.bilten.metu.edu.tr].

UNESCO (1996) Learning: The Treasure Within. UNESCO Publication, Paris, p. 15.

WB (1999) [www.worldbank.org/worldlinks/english/index.html].

Yerlici, V. (1987a) An Interdisciplinary Approach to Engineering Curriculum. In Proceedings of the 16th International Symposium, International Society for Engineering Education, Leuchtturm-Verlag, Alsbach, pp. 512-516.

Yerlici, V. (1987b) The Same Degree for All Engineering Students. In Proceeding of the European Society of Engineering Education Conference 1987, Helsinki, pp. 365-370.

Yerlici, V. (1989) A Different Approach to Formal Engineering Education. In Proceedings of the 18th International Symposium, International Society for Engineering Education, Leuchtturm-Verlag, Alsbach, pp. 130-133.

Yerlici, V. (1991) New Approaches in Engineering Education. In Proceedings of the EastWest Congress on Engineering Education, The Australasian Association for Engineering Education, Cracow, pp. 300-303.

Yerlici, V. (1992) Open Engineering Schools for the Developing Countries. In Proceedings of the 21 th International Symposium, International Society for Engineering Education, Leuchtturm-Verlag, Alsbach, pp. 612-616.

Yerlici, V. (1993) The Place of Teaching and Research in Engineering Education. In Ingenieur Pedagogik Brücke Zwischen Lehre and Forshung, A. Melezinek and G. Kurz (eds.), International Society for Engineering Education, Leuchtturm-Verlag, Alsbach, pp. 297-300.

YOK (1999) Turkish National Higher Education Council web site [www.yok.gov.tr].

\section{BIOGRAPHY}

Erol Inelmen graduated from the American Robert College in Istanbul, Turkey in 1963 as a mechanical engineer. After ten years in industry as a project engineer he joined Bogazici University in 1982. In 1992 he gained his $\mathrm{PhD}$ in engineering management from the Marmara University in Istanbul, Turkey. He is now Assistant Professor in the Faculty of Education and is involved in subjects related to project management, computer-aided design/learning and engineering education. 